\section{The Inadequate Vehicle: Dreiser's}

\section{Financier 1912-1945}

\section{By Orm Överland}

Dept. of English, Univ. of Bergen, Norway

1.

Theodore Dreiser's "Trilogy of Desire" was more than thirty years in the making. Spanning such a significant portion of his life the Trilogy provides a unique key to our understanding of the author's changing philosophy.

The theme that finally emerges from The Stoic, published posthomously in 1947, is hardly prepared for by the two preceding volumes, The Financier (1912) and The Titan (1914). The logical and perhaps the aesthetically most satisfactory conclusion of the Trilogy would seem to be with the dissipation of Cowperwood's fortune and the complete failure of all his grandiose and altruistic plans. Such was the outcome of the striking career of the businessman Charles 'T. Yerkes, the real-life model for Dreiser's fictional portrait of the American financier, and there is strong circumstantial evidence that Dreiser had planned his Trilogy as another study in futility.

If the moral of Carrie Meeber's life can be summarized in the words of the Preacher, "Vanity of vanities; all is vanity," the same text may yield an apt commentary on the life work of Yerkes: "Then I looked on all the works that my hands had wrought, and on the labor that I had labored to do: and behold: all was vanity and vexation of spirit, and there was no profit under the sun." Indeed, the career of a powerful tycoon would seem a better illustration of the theme of futility than that of the drifting and aimless Sister Carrie, "A Waif Amid Forces."

The 915 pages of notes Dreiser gathered on Yerkes include comments on the situation after his death, "his fortune plucked to the bone by 'legal vultures,' his whole world come to ashes." Richard Lehan remarks that the notes "end on the same anticlimactic and poignant note as "The Stoic." 1 The career of Cowperwood closely follows that of Yerkes also in the final dissipation of his fortune. It is essential to note, however, that The Stoic does not end with the death of Cowperwood.

The death of the financier does conclude "Victory," a short story Dreiser published in Chains in 1927. In his ruthlessness J.H. Osterman, who had accumulated his large fortune "after he had passed the age of forty," bears resemblance to both Yerkes and Cowperwood. Osterman, however, lacks both the sexual vitality and the intellectual capacity of Cowperwood. His last years are empty and meaningless:

At first it had seemed wonderful to be able to go, do, act, buy and sell as he chose, without considering anything save whether the thing he was doing was agreeable and profitable. He had thought that pleasure would never pall, but it had .... And what was the import of his success, anyhow, especially to one who had no children and no friends worthy of the name? There was no such thing as true friendship in nature. It was each man for himself, everywhere, and the devil take the hindmost. It was life that used and tossed one aside, however great or powerful one might be. There was no staying life or the drift of time.

Such are Osterman's thoughts on life, and his general sense of futility is similar to Maggie's as she sits in her rocking chair by the hotel room window.

Osterman, however, is vaguely troubled by his conscience and in an attempt to give some meaning to his life of acquisition through a final act of altruism, he decides to will his fortune to the establishment of a nationwide chain of orphanages. Before the will is signed Osterman collapses. Lying in his bed recovering from the stroke he asks to be left alone with his lawyers. A writing board is called for - "a Quija board, by the way," the lawyernarrator of this part of the story informs us - but Osterman is too weak to sign and his wife, fearing that her interests are

${ }^{1}$ Theodore Dreiser: His World and His Novels (Carbondale, IIl., 1969), p. 101. On pp. 97-106 Lehan provides the best available account of Dreiser's research and use of sources for his trilogy.

"Quotations from "Victory" are from Chains: Lesser. Novels and Stories (London, 1928). 
threatened, also tries to intervene: "he leaned forward and tried to grasp the pen. When he found he couldn't he actually groaned: 'The-the-I-I-I want to-to-do something-for-for-thethe-the- "Then he fell back, and the next moment was dead."

As late as 1937 Dreiser told Robert H. Elias that "we were all at the mercy of glandular reactions and sense perceptions and that since one's physical state controlled one's activity ... one's will was set at naught."3 Man's lack of freedom to act according to his own will was one of the basic tenets of Dreiser's view of life at the time he wrote this story, and whether Osterman's attempts to bring his life to a meaningful close are finally frustrated by fate (as suggested by the Quija board) or by the chance malfunctioning of his "physical state," man's essential helplessness is underscored: "Just an ounce or two more of strength in that old codger's system, and think what would have been done with those millions."

Thus Dreiser's notes on Yerkes as well as the short story "Victory" suggest that he had planned the last volume of his trilogy as an ironic comment on the futility of life. The ends of Osterman and Cowperwood are very similar, but by the time Dreiser came around to completing his Trilogy he had changed his mind about too many things to let his final statement be on the futility of the strivings of mankind.

The long genesis of The Stoic is not unique: The Bulwark, completed in 1945, had been conceived in 1912. While writing the first volume of the Trilogy in 1912 Dreiser counted on having the other two published by the end of the following year. ${ }^{4}$ The Titan was slightly delayed because of difficulties with the publisher and appeared in 1914. But although Dreiser immediately turned to the third volume it was hardly mentioned again in Dreiser's correspondence until 1928 when he seems to have taken new interest in his subject. In that year Dreiser wrote to Sergei Dinamov, the Soviet critic who first had suggested that Dreiser come to Russia, about the importance of explaining to Russian readers that $T$ be Financier and The Titan were "two parts of a trilogy which is still to be completed. Part three is to be called The Stoic, and I am

3 W. A. Swanberg, Dreiser (New York, 1965), p. 445

Robert H. Elias, ed., I-III (Philadelphia, 1959), p. 143. All references to letters are to this edition. about to begin work on that now. It should be ready in a year at the most" (p. 477). Obviously Dreiser was anxious that it be understood that Cowperwood's career had not come to an end.

Liveright started paying Dreiser advances on The Stoic in 1929, but three years of advances and gentle prodding had no effect. These were years that saw the awakening of Dreiser's social consciousness with the fact-finding visit to strikeridden Harlan County in 1931 as a high water mark. Throughout 1932, the year Harlan Miners Speak was published, he made attempts to get on with The Stoic ${ }^{5}$ but he was evidently troubled now by the conflict between his one-time admiration for the financier and his present involvement in the plight of the poverty stricken miners:

There is a social unbalance [in this country] which would not permit of any sane picture that did not clearly reflect social unbalance. However, at the same time that I am interesting myself in our social conditions, I am concluding the last volume of the "Trilogy which, I am sure, most of my critics will pounce on as decidedly unsocial and even ridiculous as coming from a man who wants social equity. Nevertheless, I am writing it just that way. ${ }^{0}$

Whatever enthusiasm Dreiser had once been able to muster for his Cowperwood story had long since disappeared. A new contract with Simon \& Schuster in 1935 and their constant reminders over the next two years that they were waiting for his promised novel could not make him show even perfunctory interest in The Stoic. The project that engaged his mind most deeply through most of the '30's was his never to be completed philosophical and scientific inquiry The Formula Called Man. Dreiser did not return to the Trilogy until in 1945, a few months before his death. By then, however, it seems to have become imperative that the book be completed.

This brief survey of the history of the writing of the Cowperwood Trilogy makes it obvious that it would be a mistake to expect a complete break between the two first volumes and the concluding

' See Letters, pp. 590-3, 599; Swanberg; pp. 397-8, 403-4.

6 Letters, p. 583. This view may be compared with that of a letter he wrote to Mike Gold in 1928: "Personally, I never can see Protest as literature and in these two Studies while I find some Protest, I find more of that detached observation of reality which no one with Protest only as a reason for writing can achieve. I feel that you are more the Artist than the Social Advocate and should see where your fine gift lies." (p. 472) 
one. The over-all design for the entire Trilogy was worked out before Dreiser started writing The Financier, and tying Cowperwood's career so closely to that of Yerkes made later radical departures from the original plans difficult. Moreover, parts of The Stoic were drafted in the same period the two first volumes were completed, and other parts were written at different times in the following decades. Nor should one insist on any clear and sudden break in the writer's social and philosophical attitudes. For the new attitudes and beliefs did not suddenly leap into his mind from nowhere. An examination of Dreiser's changing images of the financier as well as of the developments of some of his political and philosophical attitudes may serve to throw some light both on the problems he confronted in his attempt to bring his "Trilogy of Desire" to a conclusion and on The Stoic itself.

\section{2.}

A recurring theme in Dreiser's work up to Tragic America (1931) is the irrelevancy of moralistic judgments of human action. "For all the liberal analysis of Spencer and our modern naturalistic philosophers, we have but an infantile perception of morals," he observed in Sister Carrie (1900). The often commented upon battle between the lobster and the squid in the opening chapter of The Financier "cleared things up "considerably intellectually". for the ten year old Frank Cowperwood: "That's the way it has to be, I guess," is the financier-to-be's observation on the victorious lobster. There could be no "right" or "wrong" in a naturalistic universe and the boy could only conclude, "That squid wasn't quick enough." Both parents respond with a conventional sentiment, "Well, that's too bad," but the author would seem to have shared his hero's reaction:

An interviewer once... raised the question as to whether the American financial type, then so abundant and powerful, had ethically the right to be as it was or do as it was doing, seeing that it was being and doing about as it pleased. My answer was, and I still see no reason for changing it, that, in spite of all the so-called laws and prophets, there is apparently in Nature no such thing as the right to do or the right not to do, if you reach the place where the significance of the social chain in which you find yourself is not satisfactory. The murderer has under the written law no right to murder anybody. It is perfectly plain that he has the right if he is willing to pay the penalty, or if he can cvade it. ${ }^{7}$

One may stand with the "individualists," Dreiser wrote in Hey, Rub-A-Dub-Dub!, and acknowledge "no laws created by mass conditions and necessities," or one may feel "as so many of the less well equipped do," that "the airs and dreams of the individual in regard to his personal satisfaction" are far less important than "the general welfare of each individual of the mass." When Dreiser, however, agrees "with Nietzsche that it is folly not to wish that the significant individual will always appear and will always do what his instincts tell him to do," it is because this will be "for the subsequent good of the mass, and also that the mass only moves forward because of the services of the exceptional individual." Considering the achievements of the American financier - from the Woolworth building to the flying machine Dreiser aligns himself with those who say with enthusiasm: "Then. let us have him along with all his lacks or vices, in order that this other may be."

In Europe in 1911, when he was collecting material on Yerkes, Dreiser was fascinated by the financiers of ancient Italy. In $A$ Traveler at Forty (1913) it is obvious that the Medicis and the Borgias appealed to his imagination, and he wrote at great length of the latter in a book otherwise devoted to the contemporary scene. Compared to the Renaissance financier Dreiser found something lacking in his 20th century American descendent: even though he had certainly been "a giant or a Titan," "artistically thus far he is not much to survey." It is as if Dreiser tries to make amends for this in his Trilogy by making Cowperwood an artist in the realm of finance and by giving him the role of a 20 th century Mrecenas: "Cowperwood was innately and primarily an egoist and intellec-

${ }^{7}$ Hey, Rub-A-Dub-Dub! A Book of the Mysiery and Wonder and Terror of Life (London, 1931), pp. 93-4. The book was originally published in New York, 1920.

8 Ibid., pp. 95-6

"Hcy, Rub-A-Dub-Dub! p. 97. In a letter from 1920 he wrote: "America is too busy constructing material equipment for more life. At best art is a byproduct. It is free, surplus, joyous energy,- something over and above mene material necessity. Pethaps the American has not reached that free material state where he can afford to pause and think aside from material things, of course." (p. 331). 
tual. ... We think of egoism and intellectualism as closely confined to the arts. Finance is an art" (The Financier, p. 134). ${ }^{10}$ Cowperwood is generally not seen as acting from petty mercenary motives. He does not want money for its own sake nor "for what it will buy in the way of simple comforts," but "for what it will control - for what it will represent in the way of dignity, force, power" (p. 205)..$^{11}$

In 1927 Dreiser wrote to the Russian critic Sergei Dinamov that he had "no theories about life, or the solution of economic and political problems. Life, as I see it, is an organized process about which we can do nothing in the final analysis" (p. 450). Some months later he visited the Soviet Union. The following year the United States had the traumatic experience of the panic and the following depression. Though one should not claim any simplistic causal relationship between these happenings and Dreiser's later development, it is interesting to compare the passage from his letter to Dinamov in 1927 to the opening statement of a letter from 1931 to a General Motors executive: "I should preface my comment on this interesting book of yours ... by stating quite flatly that my solution for the difficulties of the world, and particularly those in America, is Communism" (p. 513). The bemused yet Olympian spectator on man's futile and meaningless struggles had declared himself as involved participant, and the books that followed speak not only of a marked change in attitude but of commitment.

\footnotetext{
${ }^{10}$ All quotations from the Trilogy are from the uniform edition published by the World Publishing Company (Cleveland and New York, n.d.).

"One of the most important expressions of this "dignity, force, power" is the house the financier erects for himself. In this Cowperwood would seem typical of his class. One need only consider the many assignments given to R. M. Hunt by the Vanderbilts or the town house McKim, Mead and Whit built tor Henry Villard. The lavish houses of the new financiets were among the earliest impressions Henry James recorded in The American Scene and both Frank Nortis and Edith Wharton have their tinanciets express their power aided by the architect and the artist. When Cowperwood built his new firm in Philadel phia it was essential that his home should correspond to his new position: "The houses and the bank-front of Cowperwood \& Co. had been proceeding apace" (p. 104). Chicago's and, later, New York's larger entrepreneurial ventures tequired toore magnificent homes and more valuable art collections: "until he could have a magnificent mansion acknowledged as such by all, until he could have a world-famous gallery, Berenice, millions-what did it avail?" (The Titan, p. 439). Cowperwood, however, does not seek beauty in his art collection alone. His restless quest for women as well as his struggle for control of the traction system of Chicago are expressions of his artistic temperament
}

Dreiser's earlier uncritical fascination with the American financier which had found its expression in Hey, Rub-A-Dub-Dub! has disappeared from the pages of later non-fictional works like Tragic America (1931) and America Is Worth Saving (1941). When he writes about political graft, the establishing of front construction companies or the buying of newspapers, and when he discusses the effect on the "little person" of "corporation greed in connection with railroads, streetcars, busses" in 1931, his attitude and his approach are radically different. ${ }^{12} \mathrm{He}$ is now criticizing, even castigating, where he previously was merely looking on. This muckraker approach is continued in America Is Worth Saving which has chapters like "What Are the Objectives of American Finance?" and 'Have English and American Finance Cooperated with Hitler to Destroy Democracy?"

Dreiser, however, went through other and perhaps deeper changes in the last two decades of his life than this shift in politics. In his early work Dreiser, like Stephen Crane and other naturalists before him, had found men to be "like animals in a jungle."13 In the Illinois state legislature of The Titan "a jungle-like complexity was present, a dark, rank growth of horrific but avid life-life at the full, life knife in hand, life blazing with courage and dripping at the jaws with hunger" (p. 516). As late as September 1928 Dreiser used a similar jungle image of human life in a letter to Mike Gold: "As a matter of fact humanity as a whole-the human race, no less, is a predatory organism, fighting and killing to not only save but advance and even luxuriate itself at the expense of and as against every other type of organism. If you don't believe it walk to the nearest butcher shop or visit the Chicago stockyards" (p. 474). The tone is still one of acceptance of what he regarded as the natural order of things.

Dreiser returned to the jungle image when writing the introduction to Harlan Miners Speak in 1932:

Americans today should make an intensive study of individualism as such. They will find its best exemplar in the jungle where every individual is for itself, prowls to sustain itself, and deals death to the weakest at every turn.

12 Tragic America (New York, 1931), pp. 40-1, 56-7, 222-4.

${ }^{3}$ Crane, George's Mother, Chapter Two. 
The cries of the jungle today are no more and no worse than the cries of the miners in Harlan ... or of the masses in general. They, like the zebra in the jaws of the lion, are the economic victims of these giant corporations ....

Again I say, Americans should mentally follow individualism to its ultimate conclusion, for society is not and cannot be a jungle. It should be and is, if it is a social organism worthy of the name, an escape from this drastic individualism which, for some, means all, and for the many, little or nothing. And consciously or unconsciously, it is by Nature and evolution intended as such, for certainly the thousands-of-years-old growth of organized society augurs desire on the part of Nature to avoid the extreme and bloody individualism of the jungle. ${ }^{14}$

Dreiser's fascination for the strongest animals of prey and the spectacle of the struggle for life has given way for a growing concern for the victims. The "less well equipped" are no longer brushed off and the zebra's plight is not as easily dismissed as that of the squid which "wasn't quick enough." Nature still governs life, but not blindly. It is no longer an amalgam of chemical forces but an intelligent principle. In 1937 Dreiser wrote to Robert $\mathrm{H}$. Elias that he had never undergone any radical change in attitude: "my feelings have almost always gravitated toward sympathy with what I regarded as the underdog" (pp. 784-85)..$^{15}$ Mencken, however, felt that his long time friend was not the same any longer when he wrote Dreiser in 1943, "What, precisely are your ideas about the current crusade to save humanity?" In his reply Dreiser again used animal imagery: "I know you have no use for the common man since he cannot distinguish himself. But I have just as I have for a dog, a worm, a bird, a louse or any living or creeping thing" (pp. 980-1).

Probably the most revealing instance of Dreiser's reverence for all forms of life can be found in the biography by Robert H. Elias. In 1938 Dreiser killed a puff adder, thinking it was poisonous. $\mathrm{He}$

${ }_{14}$ (New York, 1932), pp. 15-16.

15 Compassion for the weak individual is present in Dreiser's work from the beginning, but there is an important difference between the pity felt for the helpless "mass" in the following passage from 1916 and his call for action in 1932: "looking at this crowd of people here in the streets of Columbia City, 1 was more affected by their futility and pathos-life's futility and pathos for the mass - than by anything else so far What could these people do for to giants at the top?" (A Hoosier Holiday, New York, 1916, p. 279) discovered he had been in error, and the next time he came across one "he had attempted to speak to it reassuringly, saying he intended it no harm.... Dreiser had been sure the snake had understood - indeed, Dreiser had soon decided man could talk with animals or birds, perhaps even with the grass and the flowers."16 By then he had come a long way from the point of view expressed in a letter from 1920: "We do not worry much, as you well know, about helps or harms which befall flies, snakes, chickens, etc., although these are genuine harms and helps and so goods and evils to them .... The whole of so-called abstract justice falls usually and very specially within the race. It does not extend to things outside.... You are mixing up religious balderdash with chemical and physical facts or laws" (pp. 285-86).

In the same period Dreiser became involved in social action he himself became interested in "religious balderdash." The man who had referred to religion as a bandage for sore brains suggested toward the end of his life the building of an edifice dedicated "to the helpful spirit of religion." 17 His often contradictory statements on religion point to the late 30's as a turning point in his development. Elias writes of Dreiser's visit to the Long Island Biological Association laboratories during the summer of 1937 and makes a claim for this as the crucial experience which had made him decide that "the creative force was after all not blind but intelligent."18 The notion that Nature or "the creative force" was intelligent, however, had been present in his mind at least by 1932 when he wrote the introduction to Harlan Miners Speak. Nevertheless, it would appear that even by 1937 Dreiser was still undecided. Elias omits mention of some conflicting statements Dreiser made to him that very fall: "He said he could go into the laboratory and prove there was no free will, that we were really controlled by glands, chemism, hormones, and compulsions."19 The contrast is striking between this statement and the answer he gave his niece in 1944 when asked whether he believed in God: "I not only believe in God," he said, "but I can go into any scientific laboratory and

is Theodore Dreiser: Apostle of Nature (New York, 1949), p. 288.

17 Elias, p. 284

${ }_{18}$ Elias, pp. 289-90

19 Swanberg, p. 444. 
prove His existence."20 Although there may not be much more room for free will in a universe where all things "are emanations and evolutions of cosmic forces and cosmic law," as he wrote in a letter in 1940 (p. 887), than in one governed by "chemical and physical facts or laws," the difference in feeling behind these two terminologies is considerable.

\section{3.}

Dreiser's Trilogy was firmly based on political and philosophical views inimical to the author who eventually emerged from the 30's. To complete the series along the lines laid down in the first two volumes, as he in 1932 had insisted was his intention, could not but appear increasingly meaningless as time was running out. As matters stood, however, Dreiser had little actual choice when he finally decided to return to the manuscript for the last time. The old Cowperwood would by necessity have to remain essentially unchanged and the new Dreiser somehow be grafted on the existing structure. Consequently, one of the most obvious differences between the first two thirds of The Stoic and the previous volumes is the marked drop in quality, the sign of the author's failing fascination with his project.

Although there are no abrupt changes in Cowperwood's character in the opening chapters, some modifications are apparent from the very beginning. While Cowperwood has not been given to reflections on his code: "I satisfy myself," a new note is sounded when he first explains the principle he has lived by in The Stoic:

I have no excuses to offer for the way I am .... Intelligently or unintelligently, I try to follow the line of self-interest, because, as I see it, there is no other guide. Maybe I am wrong, but i think most of us do that. It may be that there are other interests that come before those of the individual, but in favoring himself, he appears, as a rule, to favor others. (p. 4)

The code is the same but is no longer offered in the same blunt and brusque way as of old. For even though he may "have no excuses

\footnotetext{
${ }^{20}$ Swanberg, p. 502
}

to offer," he does seem to feel the need of some self-justification. ${ }^{21}$ This need may in part be a function of his increasing age as are other aspects of Cowperwood's character in The Stoic.

When Cowperwood's physician advises him to get his mind off his underground system he is told that "some of these burdens are not so easy to drop as you may imagine. They concern the interests of hundreds of people who have put their complete faith in me, besides millions of Londoners who have never been able to travel beyond the limits of their own neighborhoods" (p. 239). Dreiser seems more interested in justifying his aging capitalist than in exposing him. The welfare of the common man had certainly not been foremost in the mind of the organizer of the Chicago traction system. Throughout The Stoic Cowperwood shows a growing concern for the well-being of others. He has qualms when he dismisses a faithful lieutenant and his concern for his wife is not a matter of expediency only. But such sentiments are nevertheless not allowed to interfere with his code: "He knew only too well that out of sentiment came nothing that was sufficient in any crisis to warrant its preservation. If life had taught him anything, it had taught him that. And he was not one to turn from his most relentlessly cruel and yet constructive teacher" (p. 124).

Although altruism thus never emerges as a driving force behind the London venture, it was nevertheless approached in another spirit than those of Philadelphia or Chicago: "this last and greatest of his financial adventures... should be on a higher level than any of his previous enterprises, and so atone for all sins coupled with his customary jugglery." The means applied, however, are basically the same: "In his heart, of course, he was by no means prepared to give over entirely his old tricks..." (p. 37). Indeed, it seems that his more lofty goals are primarily inspired by Berenice.

${ }^{21}$ At times he may even appear to have a troubled conscience, as when he muses on his plans for Aileen: "And here he was now, about to arrange with a somewhat déclassé social dandy to undertake a form of diversion which. would preoccupy her in order that he might enjoy himself blissfully and peacefully with another woman. Really nothing short of a form of moral degradation! He fully realized that. But what else was he to do? What he was now planning must be as it was because it sprang out of conditions which life itself, operating through him and others, had created and shaped, and in any event not to be changed now. It was too late. He must work out matters bravely, defiantly, ruthlessly so as to overawe people into accepting his methods and needs as inevitable." (p. 47) 
Moreover, as he frequently reminds himself, "He was already a multimillionaire, so why should he continue this money-grubbing to the day of his death?" (p. 14) Only his desire "to go forward and round out his career in some such climactic fashion as this" (p. 154) keeps him going through his last illness.

The wish to create something lasting that would transcend the money-grubbing aspects of his life is present in Cowperwood from the early stage of his career. Throughout The Titan he showed a growing concern for his art collection and his New York mansion, and towards the end of his Chicago venture he began to see beauty as the ultimate end of his quest for power and fame. In addition to the art gallery Cowperwood is in The Stoic increasingly concerned with another donation for the benefit of mankind: a hospital in the Bronx.

One reason why the reader may have difficulties in taking interest in Cowperwood's financial involvement in London is that he hardly seems very interested himself. His primary concern is with ulterior achievements and he looks forward to the day when he could retire from business and use his wealth to "maintain his art gallery, organize his charities, build the hospital to which he had given much thought in the past, and at the same time leave to all to whom he felt obligated an unquestionably satisfactory reward. The dream enticed him" (p. 200). In The Financier and The Titan financial manipulations hold the center of the stage; in The Stoic they are out in the wings.

In the first two thirds of the Trilogy Cowperwood stands out as a natural force in a universe blindly governed by chemical reactions. He moves with an irresistible strength through the financial and political worlds of two major cities and when temporarily brought down it is as if by chemical combinations for the time being more powerful than himself. Apparently Dreiser had been riven away in his fascination for the force Cowperwood represented. Eventually, all was to have been in vain, but this Dreiser seems to have accepted only intellectually. He could not work any premonition of the end into the story itself. It is as if on concluding the two earlier volumes he had decided that Cowperwood had grown to seem stronger than he really was (or ought to be): hence the editorial intrusions at the end of both novels with references to the witches of Macbeth and other warnings of the ultimate obliteration of the Titan and all his work.

In The Stoic Cowperwood's innate force is still insisted upon but hardly made credible. Earlier Dreiser had had to resort to editorial intrusions to tone down the impression of an irresistible Cowperwood. In The Stoic, where the prophecies of the witches are fulfilled, this was not necessary. Now, on the other hand, Dreiser seems to have felt the need to intrude and remind us of the power of Cowperwood's personality. ${ }^{22}$ Since Dreiser evidently still wanted him to be felt as the same living force as earlier, the change in Cowperwood's character should not merely be ascribed to his age but to a shift in the author's attitude that made it impossible for him to bring the old Cowperwood to life.

Although Cowperwood is not an old man in The Stoic (he is not much more than sixty when he dies) Dreiser starts preparing us for his death early in the novel. In the second paragraph his age is brought up as the first of two problems confronting him at the time of his Chicago defeat: "He was nearing sixty, and while seemingly as vigorous as ever, it would be no easy matter, he felt, with younger and equally resourceful financiers on the scene, to pile up the great fortune which assuredly would have been his if his franchise had been extended." The qualifier "seemingly" is hardly noticed at this point, but gains in significance as the premonitions of old age, exhaustion, and death keep piling up. The first of these are of a psychological rather than a physical nature. Cowperwood is increasingly prone to reflections on the passage of time: "Time! Time! Time! Always the erosive process at work!" (p. 41) Before he is aware of any serious ailment Cowperwood begins to tire easily. Reflecting on his difficulties after a conversation with Stane he felt that "his position in almost all of its aspects was care-full and trying. He was fagged, and disconcerted. Perhaps the first premonitory breath of the oncoming winter of age" (p. 154). At the death of Caroline Hand, one of his Chicago mistresses, he cannot avoid reflecting, "How much was there for him?" Still, however, he felt confident: "He was getting along" (p. 185). Then comes his own sudden illness and the doctors' death sentence, and from this point thoughts of death and the purpose of life naturally

\footnotetext{
${ }^{22}$ See for instance, The Stoic, pp. 123, 166, 191.
} 
command the center of Cowperwood's imagination. The grand tomb for himself and Aileen, conceived of before the full realization that the end was only a year away, takes its place beside the art gallery and the hospital as the financier's final bid for immortality.

The first impulse to have a tomb erected came to Cowperwood when visiting the Père-Lachaise cemetery. The sight of "ribbontied bouquets of roses and lilies" on the grave of Chopin "caused Cowperwood to question the likelihood of flowers being strewn over his own grave, even a year after his death..." $\mathrm{He}$ is yet more deeply moved by the "obviously refined and very attractive woman" who strew "multicolored blossoms" on the tomb of Héloïse and Abelard:

this colorful and moving incident set up a train of thought in Cowperwood's mind which related to himself and the Aileen of his earlier days.... Suddenly there flashed into his mind the idea of a tomb for the two of them, a beautiful and enduring resting place. Yes, he would employ an architect, secure designs, he would build a beautiful tomb which would commemorate the fact that at least at one time he had cared for her as much as she cared for him. (pp. 225-6)

Thoughts of beauty and love retain their hold on Cowperwood to the very end. The old Cowperwood, however, remains as immune to religion and thoughts of transcendence as the young.

With Cowperwood's awareness of time passing and of his own approaching death there is a growing sense of the futility and senselessness of not only his latest financial venture but of all life. Canterbury cathedral is a monument not to Christianity but to his own code. The "carefully executed shrine" was there " because of the hands and brains, aspirations and dreams of selfish and selfpreserving creatures like himself":

And now they were within its walls, graced and made respectable, the noble dead! Was any man noble? He was scarcely prepared to believe it. Men killed to live-all of them- and wallowed in lust in order to reproduce themselves. In fact, wars, vanities, pretenses, cruelties, greeds, lusts, murder, spelled their true history, with only the weak running to a mythical saviour or god for aid. And the strong using this belief in a god to further the conquest of the weak. And by such temples or shrines as this. He looked, meditated, and was somehow touched with the futility of so much that was still so beautiful. (p. 137)
On the way home to New York for the last time "Cowperwood felt alone, spiritually alone, at last admitting to himself that neither he nor any man knew anything about life or its Creator" (p. 247), but such faint stirrings of religiosity are never allowed to shake his naturalistic philosophy. After his last meeting with Aileen he is left "with a sense of the probable futility of it all." The premonition that all his plans for the use of his vast fortune may disintegrate with him gives him no desire to see it through himself. On the contrary, he has become "bored and spiritually dubious of the import of life itself" (p. 262). This pessimistic view of life is quite consistent with the basic philosophy that has governed Cowperwood's life from the beginning and which occasionally surfaced when "in his leisure moments - those free from practical calculation, which were not many - he often speculated as to what life really was" (The Titan, p. 11).

As far as the career of Cowperwood is concerned, Dreiser held closely to the original blueprint, and the eventual dissolution of his fortune parallels that of Yerkes': the newspapers print articles on how his millions "had faded like a dream." "What Availeth It?" asked one journalist (T he Stoic, p. 303). In this respect Dreiser had indeed written "it just that way."

The author of The Stoic is even less inclined than the author of the earlier two volumes to condemn his capitalist hero. On the contrary, it is evident that the aging socialist feels compassion for the aging financier. There is not the least suggestion of any criticism of Cowperwood's way of life nor of "the capitalistic set-up." Indeed, only once is the word "capitalistic" used in The Stoic in a passing reference to "William Jennings Bryan, a political firebrand, who, with economic and social theories somewhat at variance with the current capitalistic views of how money should be managed and divided, was seeking to bridge the then unbridgeable gulf between the rich and the poor" (p. 172). When virtually the only phrase in the novel that may be construed as a reference to the author's changed social and political views since the conception of the Trilogy is "the then unbridgeable gulf" it is obvious that Dreiser has not wished to change his point of view as far as Cowperwood is concerned in the last volume.

Cowperwood can impossibly be made to express any of the 
positive values Dreiser must have felt it imperative to incorporate into his last book. To have Cowperwood emerge as repenting sinner or as victorious spokesman for a belief in the brotherhood of man were alternatives ruled out both by the logic of the overall structure inherent in the first two thirds of the book and by Dreiser's own integrity as an artist. ${ }^{23}$ 'The message Dreiser eventually had in mind for his Trilogy was so different from the lesson in the blindness of desire and futility of life he had first envisaged, that Cowperwood could no longer serve as his vehicle.

In order to incorporate his newly arrived at view of life in his last novel, Dreiser developed another character as repository. Before his death Cowperwood laid aside all concern for the things that had meant most to him, his financial ventures as well as the monuments to his memory provided for in his will. In the end only Berenice meant anything to him. The Stoic is as much Berenice's novel as it is Cowperwood's. Dreiser switches horses, so to speak, in the third lap. From the beginning Berenice is given almost as much attention as the financier himself and the last fifty pages are hers alone.

At the outset she seems an unlikely character for the role she is given to play in the conclusion. She is in no sense a foil for Cowperwood's character. On the contrary she is closely associated with the main driving forces in his life: desire for power and desire for love and beauty. When Berenice came to him after the Chicago defeat Cowperwood felt that at last "he had the love of a woman who could truly support him in his quest for power, fame, prestige" (p. 2). His last bid for power was inspired by Berenice who had first suggested he look into "the traffic situation in London" (p. 11). Berenice is as amoral as her lover. Indeed, even Cowperwood is at times troubled by her ruthlessness in pursuit of her aims. It.was, after all, Berenice who had first suggested the possibility of providing Aileen with a male companion. "He had seized upon it as the only way to happiness with her, and so it was. Still, what of a mind that could think so shrewdly and ruthlessly? Might it not one day be turned on him? And then, what, since

${ }^{23}$ The Bulwark (1946) did not present such problems and the final version could be completely rewritten to serve as a vehicle for Dreiser's changed view of life since the first conception of the story of Solon Barnes in 1910. he cared so much?" (p. 148) At times the girl, with whom Cowperwood felt he could have "a genuine union of understanding and affection" (p. 2), appears a scheming and calculating woman as when she considers the pros and cons of a possible match with Lord Stane (pp. 179-80).

Berenice's aestheticism also relates her to the financier who, we remember, was an artist in his own right. For Cowperwood she was the one woman who "had brought something besides passion and cleverness into his life, something sensitively involved with beauty and creative thought". (p. 184). Where Cowperwood, however, "desired money in order to release its essential content, power, to be used by him as he pleased, Berenice appeared to demand the privilege of expressing her decidedly varied temperament in ways which would make for beauty and so satisfy her essentially aesthetic ideals" (p. 6). Indeed, Berenice seems selfcentered, her vision limited, compared with Cowperwood. Where he is the artist, she is merely the aesthete: "She desired not so much to express herself in a given form of art as to live so that her life as well as her personality should be in itself an art form. She had more than once thought, if only she had great wealth, very great power, how creatively she would use it. She would never waste it on great houses and lands and show, but rather surround herself with an atmosphere which should be exquisite and, of course, inspirational". (pp. 6-7). And as aestheticism is basically amoral, so Berenice claims, "I am more interested in the lovely things money can accomplish than I am in how it is made" (p. 179).

Her attitude to religion is essentially that of the younger Dreiser. She thinks of religion, at one point, as a possible pacifier for Aileen, as literally "a bandage for sore brains," as Dreiser had characterized religion and morality in a letter in 1921 (p. 337). When she goes to church it is to satisfy an aesthetic need rather than a religious one, "more to dream over the simple architecture and agreeable service than to plead with God" (p. 19).

Berenice, for Cowperwood is "evasive, elusive, mysterious.... What would Berenice be like when next he saw her? He could not tell. And Berenice, conscious of this strangeness in herself, could not enlighten him or any other" (p. 7). Nevertheless, the first suggestion of a change in her character seems sudden and unprepared 
for. At Canterbury Cowperwood is restored from his pessimistic reflections by "occasional glimpses of Berenice, poised attentively over a cross or religious inscription.... There was about her at such moments a seemingly non-material as well as mentally contemplative grace which brushed aside the tang of that pagan modernity which at other times gave her the force and glare of a red flower in a gray rock" (p. 137). Later that day Berenice muses on "the mystery and immensity of voiceless time and space. $\mathrm{Ah}$, to have understanding, knowledge! To think earnestly and seekingly for some reason or excuse for life! Was her own life merely to be one of clever, calculating, and ruthless determination to fulfill herself socially, or as an individual? What benefit could that be, to her or to anyone? What beauty would that create or inspire?" (p. 138) This vague longing for something outside her own self is merely a harbinger of the change that is to come, and even in the period after Cowperwood's death she is rooted in aestheticism, the lowest of Kierkegaard's three stages of human development: "as she saw herself, then and before, she was wholly concerned with the beauty of life, and such creative achievements as tended to broaden and expand its experiences" (p.275).

The transcendent quality of Cowperwood's drive for power was strongly suggested towards the end of The Titan when he at last "saw clearly, as within a chalice-like nimbus, that the ultimate end of fame, power, vigor was beauty, and that beauty was a compound of the taste, the emotion, the innate culture, passion, and dreams of a woman like Berenice Fleming. That was it: that was IT" (p. 470). In The Stoic his passionate quest for beauty and for love centers on Berenice. In a delirious vision before he dies Cowperwood again relates her to something divine, and sees her as "Aphrodite! Goddess of the sea! Immaculately white!". (p. 263) In her spontaneous response Berenice expresses her own wish to qualify for such a role. But Berenice must go beyond the limitations of her egocentric aestheticism before she can express the supreme value of life and represent the full content of the chalice of Cowperwood's earlier vision. When he dies she is yet no Beatrice.

Berenice's search for understanding and knowledge takes her to India and the Guru Borodandaj in Nagpur, "who promises her that she "will lose the suffering that comes from desire" (p. 290). When she asked him about beauty which "so many people worshipped... in all its forms" and were slaves to, the Guru answered, "Even in the lowest kinds of attraction there is the germ of Divine Love" (p. 297).

But the Guru and his eastern religion can only help her on part of the road she has to travel, as Berenice realizes when confronted with the social ills of India on her way home:

She was spiritually lacerated, and there sprang into her mind the assurance of the Gurus that God, Brahman, was All Existence, Bliss. If so, where was $\mathrm{He}$ ? The thought stayed with her until it became all but unbearable, when suddenly there flamed the counterthought that this degradation must be met and overcome. And was not the All in All God speaking and directing her thus to assist, aid, change, until this earthy phase of Himself would be altered or transmuted into the exchange of evil for good? She wished so with all her heart. (p. 301)

Such a transmutation would seem to call for no less than a universal social revolution, but Berenice seeks to do her part through charity. She realizes Cowperwood's dream of a children's hospital in the Bronx and becomes a nurse:

as she now searched her conscience, what place had charity ever had in her life? What had she ever done to help others? What had she ever done to justify her right to live? True, Cowperwood had not only conceived the idea of founding a hospital for the poor, but he had done everything humanly possible to bring it into existence; even though his plans had failed. But she-had she ever had a desire to help the poor? Not that she could recall. Her entire life, as she realized-with the exception of the past few years-had been spent in the pursuit of pleasure and self-advancement. But now she knew that one must live for something outside of one's self, something that would tend to answer the needs of the many as opposed to the vanities and comforts of the few, of which she herself was one. (pp. 305-6)

Thus it is through Berenice that the apparent blindness of Cowperwood's desire can be converted to something meaningful. The longing for beauty may be seen behind the vague desires of Sister Carrie as well as behind those of the more forceful young financier from Philadelphia, but the eventual metamorphosis of such desire as interpreted by Berenice is hardly suggested in Dreiser's early work: 
And as she walked about arranging the flowers in a bronze urn on the steps of the tomb, she thought that Cowperwood must know, if he had not when he was here in the flesh, that his worship and constant search for beauty in every form, and especially in the form of a woman, was nothing more than a search for the Divine design behind all forms-the face of Brahman shining through. (p. 305)

In Père-Lachaise Cowperwood had seen the fresh flowers on the graves of Chopin and of Abélard and Héloïse, an emblem of their greatness in art and love respectively as well as of their lasting influence on human lives. When Berenice carries her flowers to Cowperwood's tomb after her return from India the parallel is obvious (although perhaps not successful). Where he had failed, she may be able to succeed for him: "She must go on, she must grow, she thought, and acquire, if possible, a real and deep understanding of the meaning of life and its spiritual import" (p. 310).

In 1919 Dreiser was asked to read an advance copy of the Norwegian novelist Johan Bojer's The Great Hunger. He found that it "evidences a love of and a hunger for beauty, which is its greatest merit," but continues: "Having said so much I must add that it fails with me intellectually... because in the end it is turned into a religious tract. His great discovery at last, the 'satisfaction for his long hunger,' is the Sermon on the Mount!... In my judgment a novel should not be a religious tract.... The artist has but one duty: to present life "in the round" (Letters, pp. 257-8). Nothing could be more indicative of the change Dreiser had undergone than the fact that he let his last novel end in a tract. Even though the religion in the conclusion is supplied by India rather than by Palestine, his text could well have been taken from Paul's first letter to the Corinthians. 